\title{
Association Relationship between Personal Variables and Awareness about Weather Information Sources by Farmers of Ranchi District of Jharkhand
}

\author{
Abhilasha Deepa Minz* \\ Assistant Professor cum Junior Scientist, Department of Agricultural Extension and \\ Communication, BAU, Ranchi, Jharkhand-834006, India \\ *Corresponding author
}

\section{A B S T R A C T}

Keywords

Awareness,

Weather,

Information,

Effectiveness,

Credibility

Article Info

Accepted:

04 December 2018

Available Online:

10 January 2019
The present research work was conducted in eight selected villages of Ranchi district of Jharkhand. It was found during investigation that awareness level of farmers about weather information sources was more in case of traditional sources and comparatively much less in case of social media. It was also found during the study that possession of weather information yielding electronic gadgets, access to internet, need of weather information, effectiveness of weather information, credibility of weather information sources, contact with extension agencies, mass media exposure, social participation, innovativeness, cosmopoliteness, family size, education and annual income were positively correlated while age was negatively correlated.

\section{Introduction}

The sources of weather and climate-related risks in agriculture are numerous and diverse: limited water resources, drought, desertification, land degradation, erosion, hail, flooding, early frosts and many more. Effective weather and climate information and advisory services can inform the decisionmaking of farmers and improve their management of related agricultural risks. Such services can help develop sustainable and economically viable agricultural systems, improve production and quality, reduce losses and risks, decrease costs, increase efficiency in the use of water, labour and energy, conserve natural resources, and decrease pollution by agricultural chemicals or other agents that contribute to the degradation of the environment (Rathore and Chattopadhyay, 2016). Thus it can be said that weather information sources play a vital role in agricultural system and farmers being at the core of the system must be aware about such sources. Awareness about weather information sources is a major challenge and this situation has been further aggravated by climate change. The application of meteorology in 
agriculture is essential, since every facet of agricultural activity depends on the weather. Plant and crop selection are functions of the climate and of normal changes of the weather.

Timing of cultural operations, such as cultivation, application of pesticides and fertilizers, irrigation and harvesting, is strongly affected by the weather (Mannava et al., 2007). A research by Ugwoke et al., (2012) claimed that although farmers are aware of climate change, they do not seem to know the cause(s). Their knowledge of climate change is mainly based on personal experience over time and information from social organizations. Elements of climate which they perceived to have changed significantly include rainfall pattern, sunlight and temperature. They seem to have perceived climate change to a fairly large extent. Perceived adverse effects of climate change include increased rainfall intensity, flooding, erosion, excessive heat and poor crop.

\section{Materials and Methods}

The present study was carried out based on primary data about socio-personal, socioeconomic and communicational attributes of respondents which were collected through personal interview with the help of structured pre-tested interview schedule. All the weather information sources available to the farmers in the study area were enlisted and farmers' awareness about them was noted.

Awareness about weather information sources was measured in a three continuum scale i.e., completely aware (2), partially aware (1) and unaware (0). The score then obtained was summed up and accordingly extent of awareness and gap in awareness was measured. In Jharkhand, Ranchi district was purposively selected. Two blocks namely Kanke block and Angara block were randomly selected out of which four villages from each block was randomly chosen. 15 farmers from each village were randomly selected for interview. Thus a sample of 120 respondents was taken.

\section{Results and Discussion}

\section{Awareness about different weather information sources}

Table 1 illustrates the awareness level of farmers about different weather information sources. It can be seen that extent of awareness about traditional sources being the source of weather information was highest as their belief towards predictability of weather and climate change by these sources was due to their strong orthodox nature.

Next to traditional sources farmers were aware about television $(91.25 \%)$ being a source of weather information. Newspaper (74.17\%) and mobile $(78.33 \%)$ were also among sources about which farmers were highly aware. Among the sources about which the farmers were least aware were the social media.

\section{Correlation between personal variables and} awareness to weather information sources

Table 2 shows the correlation between personal variables and awareness to weather information sources by the farmers.

From the results it can be said that possession of weather information yielding electronic gadgets, access to internet, need of weather information, effectiveness of weather information, credibility of weather information sources, mass media exposure, cosmopoliteness and education are positively significant at 1 per cent level of significance. Innovativeness is positively significant at 5 per cent level of significance while age is negatively correlated with awareness. 
Table.1 Awareness level of farmers about weather information sources

\begin{tabular}{|c|c|c|c|c|c|}
\hline $\begin{array}{l}\text { Sl. } \\
\text { No. }\end{array}$ & Particular & $\begin{array}{l}\text { Maximum } \\
\text { score }\end{array}$ & $\begin{array}{l}\text { Obtained } \\
\text { score }\end{array}$ & $\begin{array}{l}\text { Extent of } \\
\text { awareness (\%) }\end{array}$ & $\begin{array}{l}\text { Gap } \\
(\%)\end{array}$ \\
\hline \multirow[t]{3}{*}{1.} & \multicolumn{5}{|l|}{ Print media } \\
\hline & Newspaper & 240 & 178 & 74.17 & 25.83 \\
\hline & Magazine & 240 & 30 & 12.50 & 87.50 \\
\hline \multirow[t]{6}{*}{2.} & \multicolumn{5}{|l|}{ Electronic media } \\
\hline & Mobile & 240 & 188 & 78.33 & 21.67 \\
\hline & Radio & 240 & 140 & 58.33 & 41.67 \\
\hline & TV & 240 & 219 & 91.25 & 8.75 \\
\hline & Mobile Agriculture App & 240 & 21 & 8.75 & 91.25 \\
\hline & Websites/ Portal & 240 & 24 & 10.00 & 90.00 \\
\hline \multirow[t]{5}{*}{3.} & \multicolumn{5}{|l|}{ Social media } \\
\hline & Facebook & 240 & 51 & 21.25 & 78.75 \\
\hline & Whatsapp & 240 & 46 & 19.17 & 80.83 \\
\hline & Twitter & 240 & 10 & 4.17 & 95.83 \\
\hline & Other social media & 240 & 12 & 5.00 & 95.00 \\
\hline \multirow[t]{4}{*}{4.} & \multicolumn{5}{|l|}{ Traditional media } \\
\hline & Pujari & 240 & 229 & 95.42 & 4.58 \\
\hline & Pahan & 240 & 238 & 99.17 & 0.83 \\
\hline & Others (friends/relatives) & 240 & 234 & 97.50 & 2.50 \\
\hline
\end{tabular}

Table.2 Correlation analysis between personal variables and awareness to weather information sources

\begin{tabular}{|c|c|}
\hline Personal Variables & Correlation Coefficient \\
\hline $\begin{array}{l}\left(\mathrm{X}_{1}\right) \text {-Possession of weather information yielding electronic } \\
\text { gadgets }\end{array}$ & $0.395^{* *}$ \\
\hline$\left(\mathbf{X}_{2}\right)$-Access to internet & $0.312^{* *}$ \\
\hline$\left(\mathbf{X}_{3}\right)$-Need of weather information & $0.700^{* *}$ \\
\hline$\left(\mathrm{X}_{4}\right)$-Effectiveness of weather information & $0.888^{* *}$ \\
\hline$\left(\mathbf{X}_{5}\right)$-Credibility of weather information sources & $0.877 * *$ \\
\hline$\left(\mathbf{X}_{6}\right)$-Contact with extension agencies & 0.116 \\
\hline$\left(\mathbf{X}_{7}\right)$-Social participation & 0.028 \\
\hline$\left(\mathbf{X}_{8}\right)$-Mass media exposure & $0.619^{* *}$ \\
\hline$\left(\mathbf{X}_{9}\right)$-Innovativeness & $0.224 *$ \\
\hline$\left(\mathbf{X}_{10}\right)$-Cosmopoliteness & $0.317 * *$ \\
\hline$\left(\mathbf{X}_{11}\right)$-Age & -0.020 \\
\hline$\left(\mathrm{X}_{12}\right)$-Family size & 0.029 \\
\hline$\left(\mathbf{X}_{13}\right)$-Education & $0.354^{* *}$ \\
\hline$\left(X_{14}\right)$-Annual income & 0.040 \\
\hline
\end{tabular}


Table.3 Regression coefficient between independent variables and awareness about weather information sources (Y1)

\begin{tabular}{|c|c|c|}
\hline Variable & "b" value & "t'" value \\
\hline $\begin{array}{l}\left(\mathrm{X}_{1}\right) \text {-Possession of weather information yielding electronic } \\
\text { gadgets }\end{array}$ & -0.852 & -0.363 \\
\hline$\left(X_{2}\right)$-Access to internet & -0.273 & -0.709 \\
\hline$\left(X_{3}\right)$-Need of weather information & $1.439 * *$ & 2.8774 \\
\hline$\left(\mathrm{X}_{4}\right)$-Effectiveness of weather information & $0.115 * *$ & 3.760 \\
\hline$\left(\mathrm{X}_{5}\right)$-Credibility of weather information sources & 0.005 & 0.270 \\
\hline$\left(\mathbf{X}_{6}\right)$-Contact with extension agencies & 0.210 & 1.402 \\
\hline$\left(\mathrm{X}_{7}\right)$-Social participation & -0.194 & -1.413 \\
\hline$\left(\mathbf{X}_{8}\right)$-Mass media exposure & $0.184 *$ & 2.167 \\
\hline$\left(\mathbf{X}_{9}\right)$-Innovativeness & -0.072 & -1.820 \\
\hline$\left(\mathrm{X}_{10}\right)$-Cosmopoliteness & $0.005 *$ & 2.206 \\
\hline$\left(X_{11}\right)$-Age & -0.001 & -0.032 \\
\hline$\left(X_{12}\right)$-Family size & 0.096 & 1.333 \\
\hline$\left(\mathrm{X}_{13}\right)$-Education & 0.185 & 1.360 \\
\hline ( $\left.X_{14}\right)$-Annual income & 0.022 & 0.625 \\
\hline $2^{2}$ value: $\quad 0.825$ & & \\
\hline
\end{tabular}

Table.4 Model Summary of regression of independent variables with awareness about weather information sources

\begin{tabular}{|c|l|c|}
\hline Model No. & \multicolumn{1}{|c|}{ Variables included in the models } & Multiple $\mathbf{R}^{\mathbf{2}}$ \\
\hline $\mathbf{M}_{\mathbf{1}}$ & $\mathrm{X}_{4}, \mathrm{X}_{3}, \mathrm{X}_{8}$ & 0.821 \\
\hline $\mathbf{M}_{\mathbf{2}}$ & $\mathrm{X}_{4}, \mathrm{X}_{3}$ & 0.808 \\
\hline $\mathbf{M}_{3}$ & $\mathrm{X}_{4}$ & 0.788 \\
\hline
\end{tabular}

Regression between personal variables and awareness about weather information sources

Table 3 shows the regression coefficient of personal variables with awareness about weather information sources of the respondents and it can be said that all personal variables taken together explains 84.8 per cent variability $\left(\mathrm{R}^{2}=0.825\right)$ in awareness about weather information sources. Through regression analysis, it was found that need of weather information (1.439) and effectiveness of weather information (0.115) were positively significant at 1 per cent level of significance. Mass media exposure (0.184), Cosmopoliteness (0.005) was also positively significant at 5 per cent level of significance while rest of the variables were nonsignificant.

Table 4 shows the model summary of regression of personal variables with awareness about weather information sources. 
Different models were tested for finding their predicting capacity for variability in awareness about weather information sources. Model-1 revealed that effectiveness of weather information sources, need of weather information and mass media exposure together explained 82.1 per cent variability in awareness. Effectiveness of weather information and need of weather information explained 80.8 per cent variability and alone effectiveness of weather information explained 78.8 per cent variability in dependent variable.

In conclusion, from the above research conducted it was found that the perception of farmers about effectiveness of weather information sources, need of weather information and mass media exposure were the major variables which explained change in awareness about weather information sources. Thus it can be said that by manipulating these variables desired outcome could be obtained and gap in awareness could be minimized. The perception of farmers about effectiveness of weather information sources needs to be enhanced by providing this information in easily interpretable form and at local level. Furthermore, the farmers must be made aware about the importance of weather updates in their agricultural activities with which their need of weather information could be improvised. For better mass media exposure, the farmers must be made aware about the weather information sources already present around them and how to better utilize them. Apart from this there may be other constraints and variables which affect the awareness about weather information sources. Further research must be done keeping those factors in kind and ways should be developed to minimize such constraints.

\section{References}

Rathore, L. S. and Chattopadhyay, N. 2016. Weather and climate services for farmers in India. Int. J. Agriculture and Food Security, 65(2).

Mannava, V., Sivakumar, K. and Motha, R. 2007. Managing weather and climate risks in agriculture. Agricultural Meteorology 60: 525-528.

Ugwoke, F. O., Nnadi, F. N., Anaeto, C. F., Aja, O. O. and Nwakwasi, R. N; Crop Farmers' Perception of an Adaptation to Climate Change in Orlu Agricultural Zone of Imo State, Nigeria. Journal of Agricultural Extension 2012; 16(2):212223.

\section{How to cite this article:}

Abhilasha Deepa Minz. 2019. Association Relationship between Personal Variables and Awareness about Weather Information Sources by Farmers of Ranchi District of Jharkhand. Int.J.Curr.Microbiol.App.Sci. 8(01): 373-377. doi: https://doi.org/10.20546/ijcmas.2019.801.038 